It is well known that the Queen, unlike some other crowned women of Europe, never enters into politics, but devotes her life exclusively to her family and to works of charity. Her charitable interest, however, is not confined to the noble institutions for the improvement of the con. dition of women of the working-class and the Evangelismos, in which two institutions she is the ever-active, the leading spirit, controlling the very details, so that nothing is done without her knowledge and approval; she is even known to visit incognito the sick poor in the city of Athens.

The two physicians who took charge of the two departments, Dr. Makkas, of the internal, and Dr. Galvani, of the surgical, when the hospital was opened have been and are still the heads of these departments, are still the physicians in charge of the Evangelismos.

It is difficult to understand why communications from visitors to Greece are as a rule unfavorable to this unfortunate country. If it is true, if you agree with the idea that the position of woman is one of the most important signs of the character of a nation and of its civilization, you must surely confess that the Greeks merit our esteem in a marvellous degree.

Once I had the honor to address a select American society on my friends the Greeks. Among the audience were a number of professors of the Columbia University of this city, and one of them who had lived for a long time in Greece said in the course of the discussion, "There exists no people among whom woman is more highly esteemed than the Greeks of to-day, and this fact alone augurs for the nation a happy future."

\title{
THE INTERNATIONAL COUNCIL OF NURSES
}

\section{A MESSAgE FROM ITS PRESIDENT}

\section{THE INSPIRATION}

A WELL-DEVELOPED sense of corporate responsibility in individuals is the only sure foundation on which to build the liberties of peoples. Failure on the part of powers to cultivate the sacred sense of human responsibility has resulted in the enslavement of persons and in the degradation of nations. Hence honor, the height, the flower, the cornerstone of morality, must be the inspiration of individual conduct and the fount from which true greatness springs. The people must have knowledge to make them strong and worthy of power, and to make a human 
named after the two great philanthropists who paid the entire cost of their ercetion.

You cannot take a human being and clothe and feed it as you would a doll, and expect aught but an echo should you tap its brain, or an outflow of dry dust whence the red blood-corpuscles should spurt. Government by animal force develops cunning, as opposed to courage, in the weak as a means of self-preservation: and yet it is the heroic virtues which must be sought after and exercised by those who hopc to rise and to enjoy in all its fulness the strenuous life.

And yet virtues, to remain heroic, must be held together by the supple, rose-red ribbon of sympathy.

And fellow-feeling leads to concerted action, which forges the golden links of that international chain which will in future ages bind the peoples of the earth together, and by which they may ascend unto the everlasting hills.

\section{THE INTERNATIONAL IDEA}

The rapid march of science, and its great outcome of ever-widening enlightenment and ever-contracting ignorance, must render it more and more impossible as time goes on for the different nations of the world to remain in racial antagonism, or continue to be inspired by the pride of assumed supremacy. Indeed, there are even now signs in many directions of a desire that international friendship and mutual appreciation shall supplant the distrust and discord begotten of ignorance and greed. And with this aspiration stirring in the hearts of the worker, the philosopher, and the children of science, what could be more natural than that the women of all nations whose earthly work has to do with hcaling should aspire to forge a link in this fine chain of fellowship which shall bind together for mutual well-being the peoples of the world? Then the insignia of brute force will be obsolete, and united humanity will march forward to victory under the banner of knowledge.

There is nothing heroic or commendable in the isolation of nations. Such isolation is necessarily injurious to the national growth and intellectual expansion, and can only tend to the advantage of privileged classes of persons, maintained in idlencss by the ignorance of what are termed in Europe " the lower orders."

Great Britain is notorious for its insular prejudices, but free intercourse with its progressive, self-governing colonies and with the Americas may prove its salvation. We workers are beginning to voice the neccssity for space and light and to claim the right to live and move and have our being, and, moreover, to realize that the round world and all that dwell therein are but infinitesimal atoms in the universal whole. 


\section{THE TONGUES OF MEN AND ANGELS}

It was in 1893 that I had the privilege of attending in Chicago the meeting of the International Council of Women, and of hearing the "International Idea" sympathetically and beautifully explained by Mrs. May Wright-Sewall. I was a charmed listener, and grasped the meaning of her inspired oration, the text of which is to be found in the preamble of the constitution of the Council: "Sincerely believing that the best good of humanity will be advanced by greater unity of thought, sympathy, and purpose, we hereby bind ourselves together in a confederation of workers committed to the overthrow of all forms of ignorance and injustice, and to the application of the Golden Rule to society, law, and custom." Thus is the seed sown. What more natural than that trained nurses-a mighty army of workers ever increasing in civilized landsshould bind themselves together in a confederation for the application of the Golden Rule? Here in our exclusive little islands, governed by hereditary legislators, and where the idolatry of the Golden Calf scarifies poverty with a relentless knout, what chance of professional self-government can there be for the unenfranchised woman worker? What wonder then that British nurses under existing conditions should turn with hope to their colleagues in other and more favored lands and invite the help and strength to be gained from international union?

The idea of an International Association of Nurses appealed strongly to me. It proved to be acceptable to others, and the opportune moment for suggesting its formation arrived when the International Council of Women held its quinquennial meeting in London in 1899, and when Mrs. Sewall-the incarnation of the international idea-was in our midst. Representative nurses from America and other countries were also in London, and at the Matrons' Council Conference held during the Congress week I had a unique opportunity of suggesting a scheme for the formation of an International Council of Nurses in the following words: "I desire to bring before this meeting a question which I believe to be of international interest and importance. The nursing profession, above all things at present, requires organization; nurses, above all other things, at present require to be united. The value of their work to the sick is acknowledged at the present day by the government of this and of all other civilized countries, but it depends upon nurses individually and collectively to make their work of the utmost possible usefulness to the sick, and this can only be accomplished if their education is based on such broad lines that the term ' $a$ trained nurse' shall be equivalent to that of a person who has received such an efficient training and has also proved to be so trustworthy that the 
responsible duties which she must undertake will be performed to the utmost benefit of those entrustcd to her charge. 'To secure these results two things are essential: that there should be recognized systems of nursing education and of control over the nursing profession. The experience of the past has proved that these results can never be obtained by any profession unless it is united in its demands for the necessary rcform, as by union alone can the necessary strength be obtained. This union has bcen commenced in this country and in the United States. It remains for the nurses of other lands to follow our example and unite amongst themselves; but I venture to contend that the work of nursing is one of humanity all the world over, and it is one, therefore, which appeals to women of every land without distinction of class or degree or nationality. If the poet's dream of the brotherhood of man is ever to be fulfilled, surely a sisterhood of nurses is an international idea, and one in which the women of all nations, therefore, could be asked and expected to join. The work in which nurses are engaged in other countries is precisely the same as that in our own. The principles of organization would be the same in every country, the need for nursing progress is the same for every people, and my suggestion briefly is, therefore, that we should here and to-day inaugurate an International Council of Nurses, composed of representatives of the nursing councils of every country, a body which shall in the first place help to build up nursing councils in those countries which do not now possess any nursing organization at all, which shall afford to the nurses of all nations opportunities for the interchanging of thought and counsel, the broadening of sympathics, and the abolition of prejudices. I beg, therefore, to propose : Nurses."

"That steps be taken to organize an International Council of

This resolution was seconded from the chair by Miss Isla Stewart, president of the Matrons' Council, supported by Miss Huxley, of Dublin, and Mrs. May Wright-Sewall, and carried unanimously. A Preliminary Committee was appointed, the Council founded, and later, by international selection, the officers were elected.

The constitution as adopted was prefaced by the following preamble:

"We, nurses of all nations, sincercly believing that the best good of our profession will be advanced by greater unity of thought and sympathy of purpose, do hereby band oursclves in a confederation of workers to further the efficient carc of the sick, and to secure the honor and the interests of the nursing profession." 
The objects were defined as follows:

"(a) To provide a means of communication between the nurses of all nations, and to afford facilities for the interchange of international hospitality.

" $(b)$ To provide opportunities for nurses to meet together from all parts of the world to confer upon questions relating to the welfare of their patients and their profession."

It is an augury for future success that representative superintendents of nurse training-schools in Great Britain, the United States of America, the Dominion of Canada, the Commonwealth of Australia, New Zealand, Germany, and Holland have already accepted office on the International Council.

\section{THE INTERNATIONAL NURSING TREE}

Professions, like nations, can only flourish by the development of the individual sense of corporate responsibility. The first aim, therefore, of the International Council of Nurses is to organize nurses all the world over and make them articulate. Thus in the formation of national councils or federations of nurses graduate suffrage must ultimately be adopted as a fundamental principle.

Thus the first and most important work of the International Council will be to confer upon questions relating to the definition of the basis of education and qualifications for a trained nurse. At present no minimum standard of education, examination, or qualification exists upon which a trained nurse can demand legal status.

Rooted, therefore, in the graduate vote, the Nursing Tree will branch by delegation into alumnæ associations, blossom by delegation into national associated alumnæ, ripen into national councils of nurses inclusive of superintendents' and nursing societies, the ripe fruit of which will be seen in the International Council of Nurses, composed, we hope, in time of the delegates of national councils from every civilized country on the face of the earth.

An ambitious scheme. Why, certainly. Yet it is simple. I like big things. It is easy to predict that great importance will be attached to decisions arrived at by a body of nurses so representative of all shades of nursing opinion as those delegated to act on the International Council. It should ultimately become the deliberative assembly and supreme court of appeal of the nursing world.

\section{THE COMING CONGRESS}

It is a happy arrangement that the meetings of the International Council of Nurses are to be held at Buffalo in the same week as the 
International Congress. Delegates will be present from Great Britain, Canada, and Federated Australia, besides those in the United States, and we may hope that in addition to the business meetings of the Grand Couneil others of a less formal nature will be held, so that its objeets may be brought before the members of the Congress, and an opportunity afforded for diseussing and arousing interest in its future work.

In your "dear land of Liberty" the environment will be eminently sympathetie and eneouraging to any phase of the international movement. Au revoir.

Ethel Gorbon Fenwick.

\section{A HISTORY OF THE BUFFALO GENERAL HOSPITAL TRAINING-SCHOOL FOR NURSES *}

\section{BY LOIS MASTIN DIEHL}

In giving the history of the Buffalo General Hospital TrainingSchool for Nurses it seems neeessary to refer also to some points in the history of the hospital itself, our Training-School not being an independent institution, as are some other sehools.

About 1849 the first hospital of Buffalo-that of the Sisters of Charity-was established. The old building is still standing, having been converted into tenements.

In 1855 the need of another hospital was felt, and in December of that year the Buffalo General Hospital was organized. The work evidently progressed slowly, though surely, for it was June 24, 1858, when the building was dedieated with appropriate eeremonies and addresses by ex-President Millard Fillmore, Hon. James Putnam, Mr. Jesse Keteham, and others.

The original hospital was what is known as the "Old Building." From December 1, 1863, to October 2, 1864, the building was used for a United States Hospital. Dr. D. W. Harrington was one of the soldier patients, afterwards studying medieine. During its use by the United States an outbreak of hospital gangrene occurred which was attended with great fatality. The patients were kept in tents on the grounds when the weather permitted. Dr. John M. Brown, of Westfield, then house physieian, relates that, making his rounds through the tents one morning, he found a well-meaning but mistaken lady visitor distributing from her earriage to the patients green eueumbers and other inappropriate delicacies.

* Read before the Alumne Association January 31, 1901. 